\title{
Filter feeders increase sedimentation of titanium dioxide: The case of zebra mussels
}

\author{
Araceli D. Larios ${ }^{\mathrm{a}, \mathrm{d}}$, Rama Pulicharla ${ }^{\mathrm{a}}$, Satinder Kaur Brar ${ }^{\mathrm{a}, *}$, Maximiliano Cledón ${ }^{\mathrm{b}, \mathrm{c}}$ \\ a Institut National de la Recherche Scientifique (INRS), Centre Eau, Terre E' Environnement, 490, rue de la Couronne, Québec, QC G1K 9A9, Canada \\ ${ }^{b}$ Institut National de la Recherche Scientifique, Centre - Enegie Materieaux Telecommunications, 1650, boulevard Lionel-Boulet, Varennes, QC J3X 1S2, Canada \\ c Centro de Investigación Aplicada y Transferencia Tecnológica en Recursos Marinos Almirante Storni (CIMAS), Universidad nacional del Comahue- Prov de Rio Negro- CONICET, Güemes 1030, \\ 8520 San Antonio Oeste, Rıo Negro, Argentina \\ d Instituto Tecnológico Superior de Perote, Km 2.5. Carretera Perote-México, 91270 Perote, VER, Mexico
}

\section{H I G H L I G H T S}

- The depuration of zebra mussels occurs progressively with a rate around $5.6 \mathrm{mg}$ Ti/day

- Mussels retain Ti at a concentrations of $3.5 \mathrm{ppm}$ but lower concentration trigger complete Ti excretion

- Ti can be captured by zebra mussels freely dissolved or attached to particles of organic material (algae).

- Zebra mussel can retain Ti as a function of the $\mathrm{TiO}_{2}$ concentration

\section{A R T I C L E I N F O}

\section{Article history:}

Received 5 April 2017

Received in revised form 22 June 2017

Accepted 14 August 2017

Available online $\mathrm{xxxx}$

\section{Keywords:}

Zebra mussel

Ecotoxicology

$\mathrm{TiO}_{2}$

Bioaccumulation,bio- magnification

Sediments

\section{GRA P H I C A L A B S T R A C T}

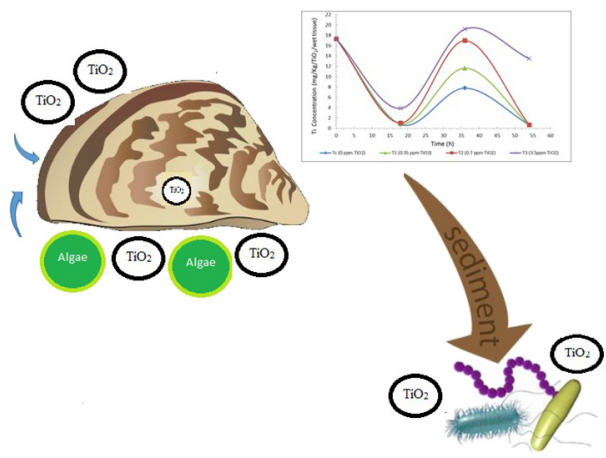

\begin{abstract}
A B S T R A C T
Titanium dioxide particles $\left(\mathrm{TiO}_{2}\right)$ are widely used to produce whitens (titanium white) and different class of nanomaterials (semiconductors, photo catalysts and nanotubes). Nanomaterials are excellent adsorbents and catalysts with a wide range of applications. However, these are reported to induce biological and genetic alterations among several invertebrate groups. Invasive species such as zebra mussels can be used as model organisms to study the behavior of particles and nanoparticles (NPs) due to their wide distribution; mussels have been extensively used for monitoring water pollution. In the present study, $\mathrm{TiO}_{2}$ particles were dispersed and added to a Chlorella culture to emulate a natural scenario. To study the reaction of zebra mussels to different $\mathrm{TiO}_{2}$ concentrations, they were fed with $0.35,0.7$ and $3.5 \mathrm{mgTiO}_{2} / \mathrm{L}$ of the suspension for 3 days and the titanium was measured in the water column, mussels and sediments with ICP-AES. Zebra mussels obtained from the Port of Quebec had up $61.62 \mathrm{mg} \mathrm{Ti} / \mathrm{kg}$ wet tissue at the time of capture. After 10 days of depuration, they had from 0.23 to $16.28 \mathrm{mgTi} / \mathrm{kg}$ wet tissue. Mussels accumulated $\mathrm{TiO}_{2}$ after $36 \mathrm{~h}$ of exposition as a function of $\mathrm{TiO}_{2}$ concentration, but mussels did not present significant mortality due to $\mathrm{TiO}_{2}$ toxicity until concentrations higher than $0.7 \mathrm{ppm}$. A second set of experiments was run to understand the $\mathrm{TiO}_{2}$ pathway attached to microalgae vs free $\mathrm{TiO}_{2}$. Results indicated that mussels accumulated slightly more Ti when it was mixed with microalgae. However, the statistical difference was non- significant. A 100 times higher accumulation of Ti in sediments was identified when mussels are present. Thus, it was concluded that the sedimentation of $\mathrm{TiO}_{2}$ is enhanced by the zebra mussels' filtration activity.
\end{abstract}

(C) 2017 Elsevier B.V. All rights reserved.

\footnotetext{
* Corresponding author.

E-mail address: satinder.brar@ete.inrs.ca (S.K. Brar).
} 


\section{Introduction}

Zebra mussels (Dreissena polymorpha) are bivalves from the Azov, Black and Caspian seas (Ricciardi et al., 1996). These were worldwide introduced during the 80 's via ballast water of trading ships and spread in different places, such as St. Lawrence River (Yoo et al., 2014), Ebro River in Castejón (Morales et al., 2013), River Rhine, Danube River, Euphrates River basin, and Kuban River among others (GISD, 2014).

The filter-feeding system of zebra mussels allows them to uptake freely dissolved or suspended chemical contaminants across its gill membrane. When the chemical contaminants are associated with particles such as algae or suspended sediments, these are desorbed during the gut passage and then these are assimilated into the mussel tissue or excreted as feces (Bruner et al., 1994). Hence, mussels have been considered as "suitable sentinel organisms" for aquatic monitoring of chemical contaminants, such as polychlorinated biphenyls (PCBs), dichloro diphenyl trichloroethane (DDT), benzo(a) pyrene (BaP), hexachlorobiphenyl (HCBP) and titanium dioxide particles $\left(\mathrm{TiO}_{2}\right)$ (Bruner et al., 1994; Couleau et al., 2012). When zebra mussels filter large quantities of water can produce then the accumulation of chemical contaminants which can be transported directly to zebra mussel predators or deposited in sediments by contaminated feces from zebra mussels (Kwon et al., 2006). It depends of the exposure time, chemical contaminants concentration and exposure route (Palais et al., 2012). Thus, detritivores such as amphipods and chironomids which inhabit in the sediment may ingest highest concentration of chemical contaminants inducing the transport and bio-magnification process through the food chain because detritivores are prey for different fish species (PerezFuentetaja et al., 2015).

In view of the widespread use of $\mathrm{TiO}_{2}$ and their environmental release into fresh water, Couleau et al. (2012) investigated the sub lethal effects of $\mathrm{TiO}_{2}$ NPs on the immune system cells (hemocytes) of Dreissena polymorpha. After $24 \mathrm{~h}$ of in vivo exposure to $\mathrm{TiO}_{2} \mathrm{NPs}$ at different concentrations, they observed the internalization of $\mathrm{TiO}_{2} \mathrm{NPs}$ into hemocytes and the consequent immunological responses. However, it is known that there are changes in the transport and behavior of NPs when these are exposed to different media such as fresh or seawater, because depending with the $\mathrm{TiO}_{2}$ concentration and the presence of organic material such as microalgae, homoagglomeration (NPs coalesce or clump together with other NPs) or heteroagglomeration (NPs are adsorbed onto cells) process may occur and to influence the bioaccumulation or sedimentation process in aquatic environments (Sendra et al., 2017). Thus, this study has examined the rerouting of $\mathrm{TiO}_{2}$ by Dreissena polymorpha for exposure experiments mediated by Chlorella microalgae at different $\mathrm{TiO}_{2}$ concentrations and exposition time from 24 to $72 \mathrm{~h}$. These results contribute for the understanding of the behavior of how these particles are transported, bio-accumulated or expelled to the sediments by Dreissena polymorpha as a function of $\mathrm{TiO} 2$ concentration, time and the presence or absence of Chlorella microalgae.

\section{Material and methods}

\subsection{Chemicals and standards}

Nitric acid (Trace metal ${ }^{\mathrm{TM}}$ grade, 67-70\% Fisher Scientific, Ontario, Canada), per-chloric acid (reagent grade 67-71\% Fisher Scientific, Ontario, Canada). Standards for metal analysis (SCP Science, plasmaCAL, Quebec, Canada). HPLC grade water was prepared in the laboratory using milli-Q/Millli-Ro Milli pore system (Milford, Massachusetts, USA). Titanium dioxide $\left(\mathrm{TiO}_{2}\right)$ powder (reagentPlus ${ }^{\circledR}$ grade, $99-100 \%$, SigmaAldrich, Ontario, Canada). Commercial fertilizer (Miracle-Gro® with 5\% N and 30\% P, Quebec Canada) was used to promote Chlorella algae growth.

\subsection{Zebra mussels (Dreissena polymorpha) conditioning}

Around two thousand specimens of zebra mussel (Dreissena polymorpha) were collected at the old Quebec port, St Lawrence River, ( $46^{\circ} 49^{\prime} 20.2614^{\prime \prime} \mathrm{N} 71^{\circ} 12^{\prime} 43.8264^{\prime \prime} \mathrm{W}$ ) in early spring 2014 and also in December 2015. The mussels attached on submerged cords and wires of the Port of Quebec yacht marina were carefully and manually collected to avoid damage of the bivalves and transported to the laboratory in a plastic container.

The mussels were cleaned with de-chlorinated tap water and transferred into five $20 \mathrm{~L}$ glass fishbowls. They were acclimated and starved for 10 days in aerated water at $15 \pm 1{ }^{\circ} \mathrm{C}$ to reduce the background content of $\mathrm{TiO}_{2}$ to the minimum. The water was daily changed, later 10 days the mussels were separated into groups of 250 mussels per treatment with a size and weight average of $2 \pm 0.27 \mathrm{~cm}$ and $1.4 \pm 0.41 \mathrm{~g}$, respectively.

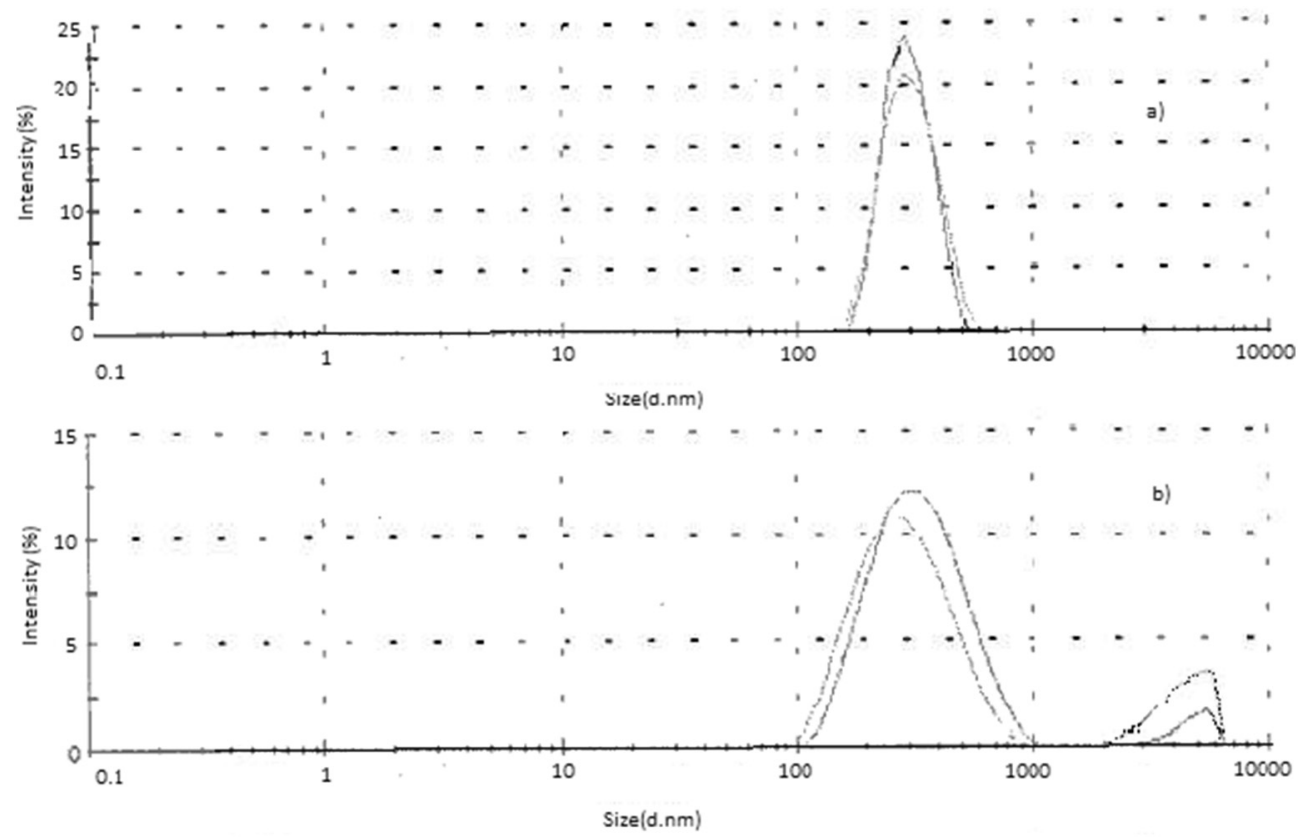

Fig. 1. Particle size of $\mathrm{TiO}_{2}$ in the solutions a) stock and b) $\mathrm{TiO}_{2}+$ algal mix complex. 


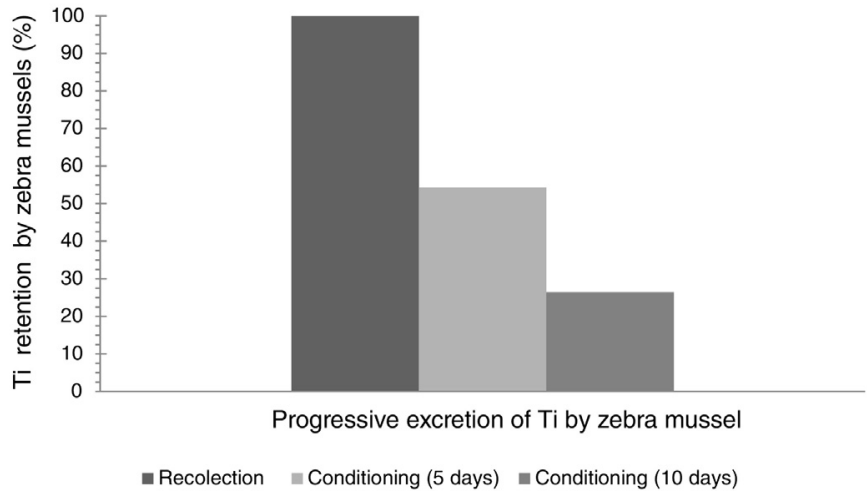

Fig. 2. Representation of the residual retention of Ti in soft tissue of zebra mussels from the day of capture until the 10th day of acclimation.

\subsection{Chlorella algae monoculture}

In order to facilitate ingestion of $\mathrm{TiO}_{2}$ by mussels, a monoculture of Chlorella was used to induce adsorption of $\mathrm{TiO}_{2}$ particles. $5 \mathrm{~L}$ Chlorella suspension was placed in a glass fishbowl for four days at $22 \pm 1{ }^{\circ} \mathrm{C}$. The suspension was exposed to natural light and aeration to maintain algal suspension and oxygen availability. About $6 \mathrm{~g}$ of commercial fertilizer and $5 \mathrm{~L}$ of chlorine-free tap water were added every $48 \mathrm{~h}$ to promote the algal growth. In a second experiment, Chlorella powder was used directly to make Chlorella algae suspension without stimulation of its growth.

\subsection{Stock solution of $\mathrm{TiO}_{2}$}

$500 \mathrm{~mL}$ of stock solution at $120 \mathrm{ppm}$ of $\mathrm{TiO}_{2}$ was prepared with milli$\mathrm{Q}$ water. The solution was sonicated for $50 \mathrm{~min}$ to maximize homogeneous dispersion (sonication $5 \mathrm{~s} / 5 \mathrm{~s}$ on/off at $40 \mathrm{kHz}$, ultrasonic homogenizer Autotune 750 W, Cole-Parmer Instruments, Vernon Hills, Illinois, US). Then, the particle diameter was measured by using a nanosizerzetasizer (model Nano-ZS, Malvern, Canada). For this analysis, $100 \mu \mathrm{L}$ of $\mathrm{TiO}_{2}$ stock solution were placed in a chamber and $900 \mu \mathrm{L}$ of milli- $\mathrm{Q}$ water were added to complete a volume of $1000 \mu \mathrm{L}$. The particle diameter was measured and it was from 100 to $400 \mathrm{~nm}$ (mean: $290 \mathrm{~nm}$ ) due to fast $\mathrm{TiO}_{2}$ agglomeration.

\section{5. $\mathrm{TiO}_{2}$-algal mix complex}

Chlorella algae monoculture and the stock solution were transferred toward a glass bowl to produce a $\mathrm{TiO}_{2}$-algal complex suspension at a concentration of $5 \mathrm{ppm}$. This solution was aerated to mix and allow adsorption of $\mathrm{TiO}_{2}$ particles on Chlorella. After that, the $\mathrm{TiO}_{2}$-algal mix solution was used to prepare the treatments evaluated in this study.

\subsection{Experimental design}

Preliminary, three treatments with $\mathrm{TiO}_{2}$ concentration of $0.35,0.7$ and $3.5 \mathrm{ppm}$ (treatment 1,2 and 3 respectively) were prepared. To do so, a volume of $0.35,0.7$ and $3.5 \mathrm{~L}$ of the algae- $\mathrm{TiO}_{2}$ complex suspension was introduced in the glass bowls and the volume was completed with chlorine-free tap water to achieve $5 \mathrm{~L}$ of solution by treatment. Additionally, a witness treatment containing $0.35 \mathrm{~L}$ of Chlorella algae monoculture free of $\mathrm{TiO}_{2}$ and $1.5 \mathrm{~L}$ of chlorine-free tap water was used as control to determine residual excretion by the mussels that could interfere with the measurements. Then, 250 mussels were placed in each bowl. The temperature in the room where the experiment was made was kept at $15 \pm 1^{\circ} \mathrm{C}$. The photoperiod was set for $8 \mathrm{~h}$ light and $16 \mathrm{~h}$ dark. All the treatments were conditioned with aerators throughout the overall experiment to maintain sufficient oxygen level and simulate environmental turbulence. Every18h, 36 and 54 h samples of around $30 \mathrm{~g}$ of mussels were drawn and immediately frozen. The rest of mussels and the bowls were washed three times at waterjet. Then, new treatment solutions with their respective concentration were prepared and placed in each bowl to maintain initial conditions. The experiment was stopped at $54 \mathrm{~h}$ of evaluation.

A second experiment was made to understand the $\mathrm{TiO}_{2}$ decantation pathway attached to microalgae vs free $\mathrm{TiO}_{2}$. For that, the same conditions used in the first experiment were repeated but, in this case, only $3.5 \mathrm{ppm}$ of $\mathrm{TiO}_{2}$ was used in duplicates, to achieve good filtration activity and low toxicity for the mussels. Then, 250 mussels were placed in each bowl. The temperature and the photoperiod in the room were kept at $15 \pm 1{ }^{\circ} \mathrm{C}$ and set for $8 \mathrm{~h}$ light and $16 \mathrm{~h}$ dark similar to first experiment. All the treatments were conditioned with aerators throughout the experiment. Every $24 \mathrm{~h}, 48$ and $72 \mathrm{~h}$ samples of around $30 \mathrm{~g}$ of mussels were drawn and immediately frozen. The rest of mussels and the bowls were washed three times with pressured water to remove all potentially attached pathogenic bacteria. Then, new treatment solution with the same concentration was prepared and placed in each bowl to maintain initial conditions. The experiment was stopped at $72 \mathrm{~h}$ of

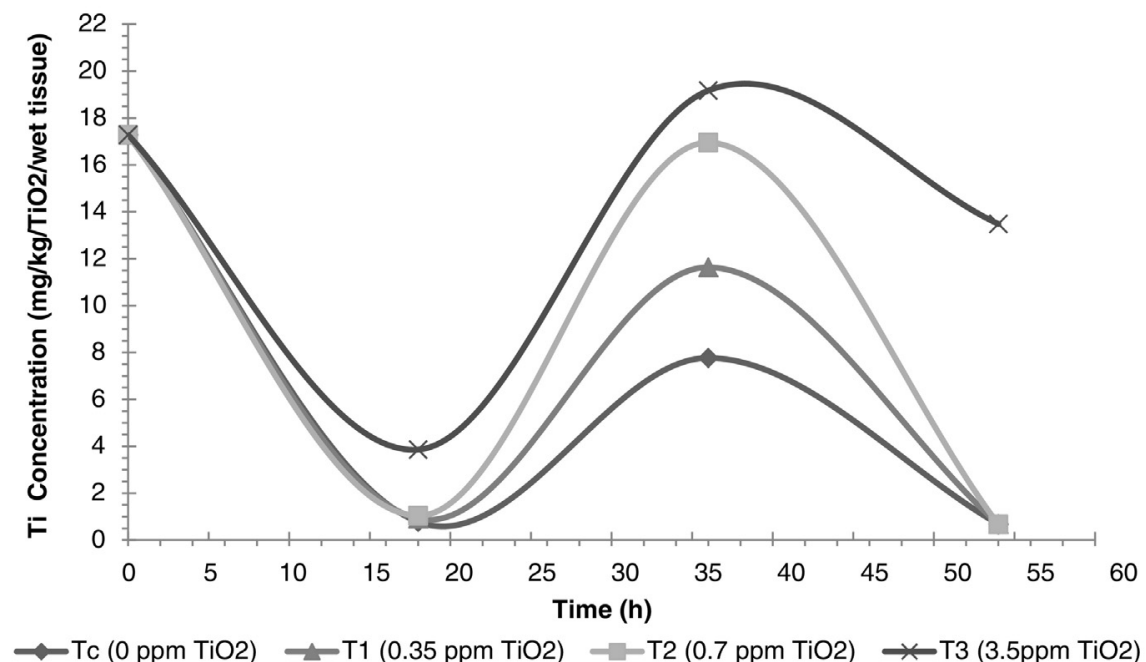

Fig. 3. Behavior of $\mathrm{Ti}$ in wet tissue of zebra mussel under different $\mathrm{TiO}_{2}$ concentration and exposure time. 


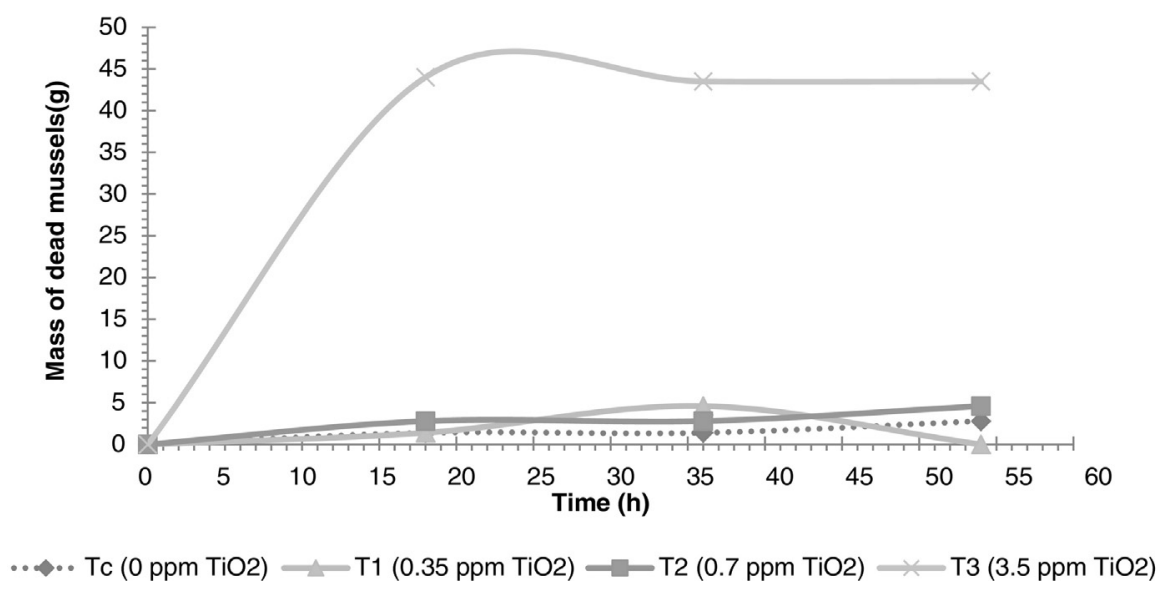

Fig. 4. Mortality of zebra mussel exposed at different concentration of $\mathrm{TiO}_{2}$.

evaluation. For Ti quantification the same process of sampling conditioning and analysis was applied.

\subsection{Sampling for Ti quantification}

At time zero and every 18 or 24 h during the whole experiment, samples of the suspension, mussels and sediments were collected from each treatment. Samples from each treatment consisted in $50 \mathrm{~mL}$ of the suspension taken from the surface, $50 \mathrm{~mL}$ taken from the bottom (sediments). Samples were stored in polypropylene tubes of $50 \mathrm{~mL}$ (Fisherbrand $^{\mathrm{TM}}$, FisherScientific, Quebec, Canada). Samples of $30 \mathrm{~g}$ of mussels per treatment were simoultaneously taken and stored in plastic bags for analysis of titanium (Ti) content. When the experiment was completed, the quantification of Ti was carried out using inductively coupled plasma-atomic emission spectrometry (ICP-AES VISTA, Canada).

\subsection{Quantification of Ti by ICP-AES}

Before the Ti quantification, the samples were digested as follows:

Liquid samples: $2 \mathrm{~mL}$ of liquid samples were transferred to Teflon tubes. Then, $4 \mathrm{~mL}$ of nitric acid and $2 \mathrm{~mL}$ of perchloric acid was added. The Teflon tubes were closed and placed in the autoclave to digest the samples. The digestion was made at temperature of 121 $\pm 1{ }^{\circ} \mathrm{C}$ and pressure around 17 psi for $4 \mathrm{~h}$.
Sediments: The samples were filtered to collect the sediments. Then, the sediments were dried at $65^{\circ} \mathrm{C}$ in an oven until constant weight. The sediments weight was registered at the nearest $0.01 \mathrm{mg}$ and the samples were transferred to Teflon tubes to make the digestion such as previously explained for liquid samples.

Mussels: The tissue of the mussels was removed from their valves. Wet tissues of mussels were dried at $65{ }^{\circ} \mathrm{C}$ in an oven until constant weight. Dry samples $(0.2 \mathrm{~g}$ ) were placed in the Teflon tubes to make the digestion similar to this made for liquid samples. Two reagent blanks were prepared with the same digestion procedures as described for the control. The digested samples were then filtered and transferred to falcon tubes of $50 \mathrm{~mL}$ (Fisherbrand ${ }^{\mathrm{TM}}$, FisherScientific, Quebec, Canada) and MilliQ water was added completing a volume of $50 \mathrm{~mL}$. After that, $20 \mathrm{~mL}$ of the conditioned samples were used to quantify the Ti concentration by ICP-AES.

Before Ti quantification, ICP-AES calibration standards of Ti ranging from 0.02 to $10 \mathrm{ppm}$ were prepared using SCP Science, PharmaCAL standards. The standards were prepared by using $\mathrm{HNO}_{3}$ (10\%). All standard and sample solutions were spiked with internal standard (IS) Yttrium (Y) $1 \mathrm{ppm}$. The spiking IS solution was taken from a single element stock solution of Y $1000 \mathrm{ppm}$. The final Ti concentration in dry weight was calculated after reading in the spectrophotometer. The operating parameters of the equipment were: Concentric glass nebulizer; nebulizer flow ( $1 \mathrm{~L} / \mathrm{min}$ ) cyclonic spray chamber; torch (quartz torch-single

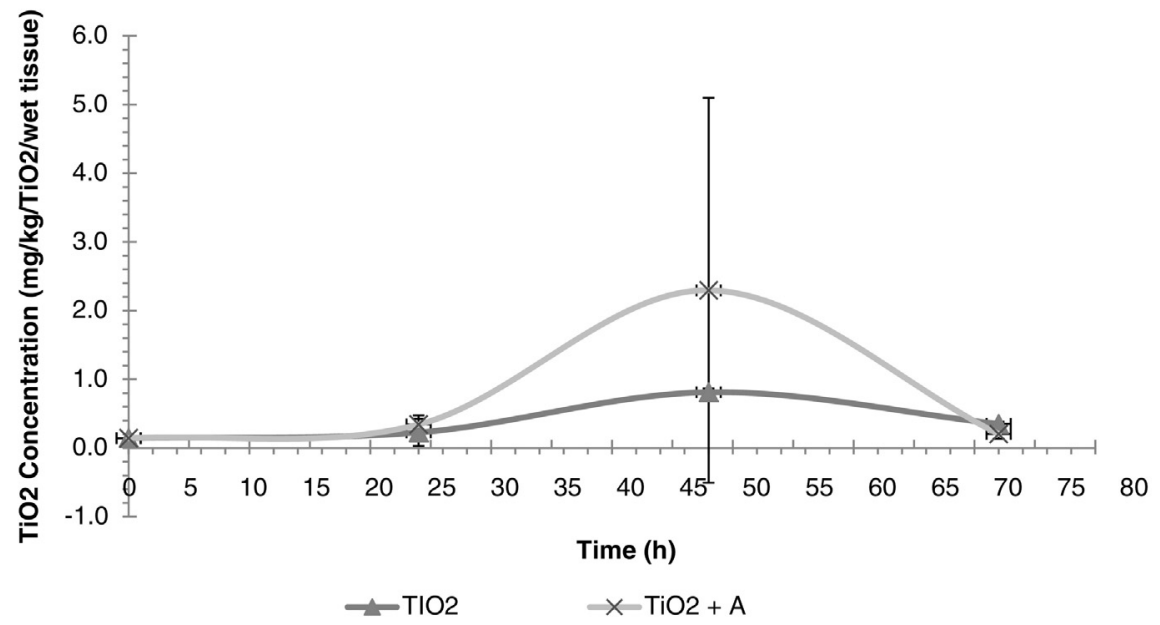

Fig. 5. Ti content in zebra mussel tissues exposed to $\mathrm{TiO}_{2}$ suspension with and without algae. 
slot); injector (glass); power (1300 W); plasma view (axial); plasma flow $(15 \mathrm{~L} / \mathrm{min})$; auxiliary flow $(2.25 \mathrm{~L} / \mathrm{min})$; sample uptake rate $(0.6 \mathrm{~mL} / \mathrm{min})$; processing mode (pick area); calibration (linear through zero); background correction (spectral background correction); integration Time (30 s); sample tubing (samples and standards white/ white, internal standard orange/white; replicates (3)). The detection limit of the instrument was $0.01 \mathrm{ppm}$.

\subsection{Statistical analysis}

An one way ANOVA was made to evaluate the significance of the observed differences between treatments. After that, a Tukey's Test for Non-additivity was made to evaluate the interaction of the data and to evaluate if the observed effect of time and Ti concentration in mussels and sediments was significant. This analysis consider a two-factor axb factorial design that has only $n=1$ replicate for each of the ab treatment combinations (time and concentration). The data analysis was made by using statistical software SAS version 9.4.

\section{Results and discussion}

\subsection{Characterization}

\subsubsection{Zebra mussels}

The mussels collected from St. Lawrence River corresponding to the species, Dreissena polymorpha had a size distribution with a mode at $2 \mathrm{~cm}$ (mean: $2.03 \pm 0.27 \mathrm{~cm}$ ). The mean weight was $1.4 \pm 0.41 \mathrm{~g}$ with a mode at $1.3 \mathrm{~g}$. Characteristics of the collected mussels matched with the description of zebra mussel in the nonindigenous aquatic species database (USGC-NAS, 2014).

\subsection{2. $\mathrm{TiO}_{2}$ particle size}

Fig. $1 \mathrm{a}-\mathrm{b}$ presents the particle size of $\mathrm{TiO}_{2}$ in the solutions stock and algae $-\mathrm{TiO}_{2}$ mix suspension.

The mean of the particle diameter in the stock suspension was around $290 \mathrm{~nm}$, while in the algal- $\mathrm{TiO}_{2}$-complex two picks were identified. These two picks suggested that in the algal- $\mathrm{TiO}_{2}$ - complex, homoagglomeration (NPs coalesce or clump together with other NPs) and hetero-agglomeration (NPs are adsorbed onto algae) could occur in same time in the suspension used. Thus, the first pick represents the unattached-algae particles and the second from the $\mathrm{TiO}_{2}$ - algae complex at around $5500 \mathrm{~nm}$ (Fig. 1a-b). Couleau et al. (2012) reported a tendency of $\mathrm{TiO}_{2}$ NPs to agglomerate in water and settle to the bottom of beakers. They explained that the suspensions used in their experiment increased the size of the NP as a function of the NP concentrations. Also, Wigginton et al., (2007) reported that NPs with different sizes can form agglomerates ( $>1 \mu \mathrm{m}$ immediately form agglomerates after their release into the environment). Such observations support the present results of agglomeration of $\mathrm{TiO}_{2}$ particles. The longer the particles are mixed in a natural matrix, the higher the possibility of agglomeration with diverse materials and get "hidden" by a heterogeneous

Table 1

Analysis of variance to evaluate the effect of $\mathrm{TiO}_{2}$ concentration and exposure time in the Ti concentration in the wet tissue of zebra mussel assuming no-interaction. The significant values are highlighted in bold.

\begin{tabular}{llllll}
\hline Source & $\begin{array}{l}\text { Degrees of } \\
\text { freedom }\end{array}$ & $\begin{array}{l}\text { Sum of } \\
\text { squares }\end{array}$ & $\begin{array}{l}\text { Quadratic } \\
\text { mean }\end{array}$ & $\begin{array}{l}\mathrm{F} \\
\text { Value }\end{array}$ & $\mathrm{Pr}>\mathrm{F}$ \\
\hline Model with non-interaction & 5 & 444.42 & 88.88 & 7.29 & $\mathbf{0 . 0 1 5 7}$ \\
Error & 6 & 73.16 & 12.19 & & \\
$\mathrm{TiO}_{2}$ concentration & 3 & 154.90 & 51.63 & 4.23 & 0.0629 \\
$\quad \begin{array}{l}\mathrm{Time} \\
\text { Tukey's Test for Non-additivity }\end{array}$ & 2 & 289.53 & 144.76 & 11.87 & $\mathbf{0 . 0 0 8 2}$ \\
$\quad$ & & & & & \\
$\quad \mathrm{TiO}_{2}$ concentration & 3 & 154.90 & 51.63 & 3.70 & 0.0967 \\
$\quad$ Time & 2 & 289.53 & 144.76 & 10.36 & $\mathbf{0 . 0 1 6 7}$ \\
Interaction & 1 & 3.32 & 3.32 & 0.24 & 0.6467 \\
\hline
\end{tabular}

Table 2

Analysis of least squares means to evaluate the significant difference among treatments with different $\mathrm{TiO}_{2}$ concentration. The significant values are highlighted in bold.

\begin{tabular}{|c|c|c|c|c|}
\hline \multirow[t]{2}{*}{$\mathrm{i} / \mathrm{j}$} & Treatment 1 & Treatment 2 & Treatment 3 & Treatment Control \\
\hline & \multicolumn{4}{|l|}{$\operatorname{Pr}>F$} \\
\hline Treatment 1 & & 0.5605 & 0.0296 & 0.6788 \\
\hline Treatment 2 & 0.5605 & & 0.0679 & 0.3337 \\
\hline Treatment 3 & 0.0296 & 0.0679 & & 0.0169 \\
\hline Treatment Control & 0.6788 & 0.3337 & 0.0169 & \\
\hline
\end{tabular}

crown. It is difficult to predict or simulate therefore natural agglomerates in experimental settings.

\subsection{Ti retention-excretion by zebra mussel}

The initial and progressive retention of Ti measured in the wet tissue of collected mussels is indicated in Fig. 2 . The $100 \%$ corresponds to the initial Ti concentration in mussels which was around of $62 \mathrm{mgTi} / \mathrm{kg}$ wet tissue. This value was 10 times higher than previously reported for the species (Bourgeault et al., 2015) and can be attributed to the exposition level of chemical contaminants in the period (summer 2014) and place in which mussels were collected. Because, it is known that in summer mussels tend to accumulate more contaminants due to the increase of filtration rates (Palais et al., 2012). Also, it was observed that after 5 and 10 days of mussels conditioning in chlorine-free tap water, the concentration was progressively decreasing to 54 and $26 \%$ respectively comparing to initial Ti concentration in mussels (Fig. 2). Thus, the rate of Ti deposition was around $5.6 \mathrm{mg} /$ day in the first 5 days, but after 5 days the rate of Ti deposition decreased to $3.4 \mathrm{mgTi} / \mathrm{day}$. This behavior can be explained due to that during conditioning zebra mussels were not fed and it could expose them to nutritional stress which decreased their metabolic activity (Palais et al., 2012).

After 10 days of conditioning, the Ti concentration in mussels was around $16.3 \mathrm{mgTi} / \mathrm{kg}$ wet tissues. This concentration was established as the initial concentration at time zero when the mussels were exposed to different treatments of $\mathrm{TiO}_{2}(0.35,0.7$ and $3.5 \mathrm{ppm})$ during 3 days. Results of the Ti concentration calculated in the wet tissue of mussels at different time are showed in Fig. 3. Results suggested that mussels had the capacity to adsorb and eliminate quickly the Ti adsorbed in the first $18 \mathrm{~h}$, because Ti did not stay in the solution neither in mussels. However, after $36 \mathrm{~h}$, mussels adsorbed $\mathrm{Ti}$ as a function of the $\mathrm{TiO}_{2}$ concentration used by treatment and then it was excreted before $54 \mathrm{~h}$ ( $\mathrm{Ti}$ concentration was very close to zero), except in the case of treatment 3 (3.5 ppm). According with the behavior showed in Fig. 4 the rate of $\mathrm{Ti}$ excretions was decreasing in time. Because the second dose of $\mathrm{Ti}$ given to mussel at $18 \mathrm{~h}$ was excreted after $36 \mathrm{~h}$ except for treatment 3. It indicates that mussel tissues reach a threshold in which a depuration mechanism is activated but can be limited at high concentration of Ti (treatment 3). Bourgeault et al. (2015) reported that zebra mussels are able to eliminate completely the Ti after $24 \mathrm{~h}$ of exposition of $\mathrm{TiO}_{2}$ at $1 \mathrm{ppm}$. However, the results in the present study indicate that it will depend of the Ti concentration and exposure time. Taking into account the low Ti concentration present in rivers, the route of Ti transport from mussels through the food chain is mainly through feces deposition and not through mussel predators. On the

\section{Table 3}

Analysis of least squares means to evaluate the significant difference among treatments exposed at different exposure time. The significant values are highlighted in bold.

\begin{tabular}{llll}
\hline $\mathrm{i} / \mathrm{j}$ & $\frac{18 \mathrm{~h}}{\operatorname{Pr}>\mathrm{F}}$ & $\underline{36 \mathrm{~h}}$ & $\underline{54 \mathrm{~h}}$ \\
\hline $18 \mathrm{~h}$ & & $\mathbf{0 . 0 0 3 8}$ & 0.4382 \\
$36 \mathrm{~h}$ & $\mathbf{0 . 0 0 3 8}$ & & $\mathbf{0 . 0 0 9 6}$ \\
$54 \mathrm{~h}$ & 0.4382 & $\mathbf{0 . 0 0 9 6}$ & \\
\hline
\end{tabular}




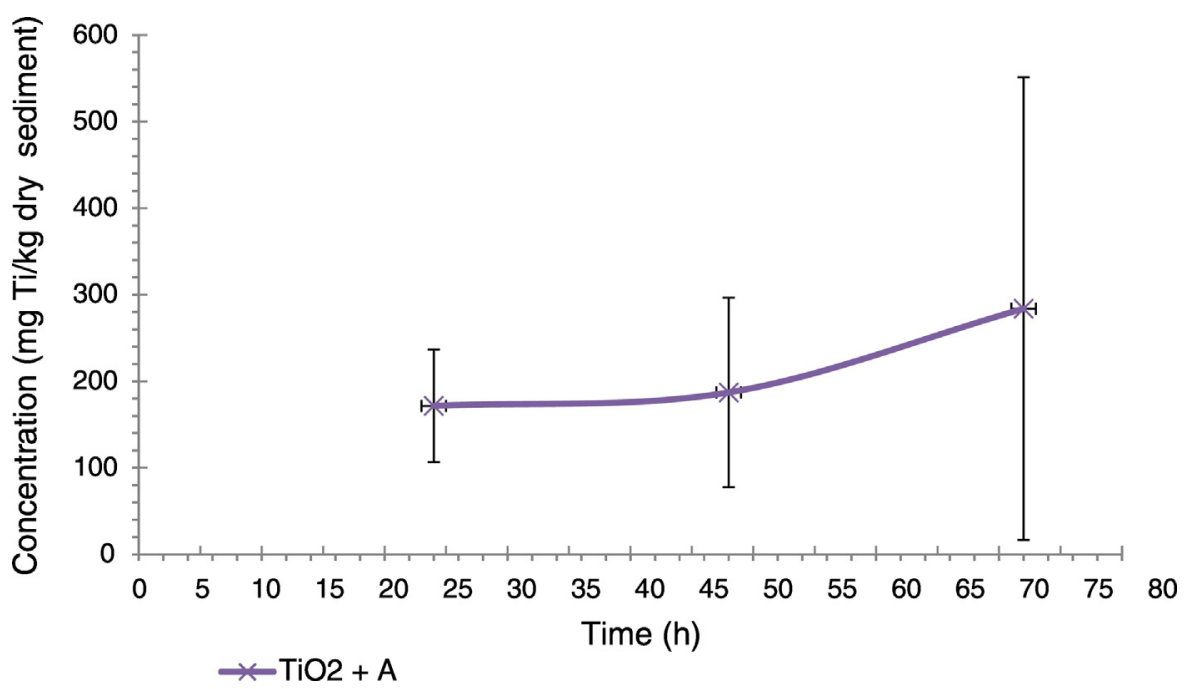

Fig. 6. Ti content in sediments as a function of exposure time of mussels to $\mathrm{TiO}_{2}$.

other hand, during the experiment it was observed that around $43.67 \mathrm{~g} /$ day \pm 0.24 of mussels were dead (Fig. 5) in the treatment 3 $\left(\mathrm{TiO}_{2}\right.$ concentration of $\left.3.5 \mathrm{ppm}\right)$. This mortality was higher respect to other treatments in which the mass of dead mussels was only from 1.87 to $3.4 \mathrm{~g} /$ day. Considering the fact that the metal detoxification and the maintenance of detoxification mechanisms might be energetically expensive, the $\mathrm{TiO}_{2}$ concentration used in the treatment 3 could affect the homeostasis of the organisms and also their metal detoxification capacity. Thus the increased energetic cost by stress expression and finally produce the mussels mortality (Smolders et al., 2004; Voets et al., 2009).

To evaluate the significance of the filtration activity of mussels on the $\mathrm{TiO}_{2}$ decantation, Tables $1-3$ show the results from the analysis of variance (ANOVA). The least squares means evaluate the effect of $\mathrm{TiO}_{2}$ concentration and exposure time in the wet tissue of zebra mussel (Montgomery, 2001). The $\operatorname{Pr}>\mathrm{F}$ value in Table 1 indicates that the model assumes no-interaction and therefore, it can estimate the difference among the treatments at a significance level $\alpha \leq 0.05$ and that the observed effects can be attributed to the evaluated variables and not to the interaction. To corroborate this observation a Tukey's test for nonadditivity was performed. The results are showed in Table 1 indicating that the main differences among treatments can be attributed to the exposure time and not to the changes among the $\mathrm{TiO}_{2}$ concentrations evaluated in the experiment $(\alpha \leq 0.05)$. Thus, to elucidate each one of the difference between the treatments a least squares means test was made and results are showed in Table 2, which show that the observed difference among the treatments was significant only between the treatment 1 and 3; 2 and 3; and control and 3 at an significant level $\alpha$ $\leq 0.05$. Table 3 presents the differences among the exposition time. It can be seen that the main changes in the Ti concentration in the mussel tissues were significant between 18 and $36 \mathrm{~h}$; and also between 36 and $54 \mathrm{~h}$. Thus, it can be concluded that only at $\mathrm{TiO}_{2}$ concentration of $3.5 \mathrm{ppm}$, a significant difference in Ti concentration in the wet tissues of zebra mussels can be identified and that the main changes occur around $36 \mathrm{~h}$ of $\mathrm{TiO}_{2}$ exposition. On other hand, a similar statistical test was made to evaluate the effect of $\mathrm{TiO}_{2}$ concentration and exposure time on the mass of dead mussel. Results showed a significant effect only between the treatment with a $\mathrm{TiO}_{2}$ concentration of $3.5 \mathrm{ppm}$ and the other treatments ( $\mathrm{Pr}>\mathrm{F}=0.0001)$. In this case, the exposure time has no effect on the mass of dead mussel $(\operatorname{Pr}>\mathrm{F}=0.8428)$.

As complement to the understanding of Ti retention-excretion behavior by zebra mussels, a second set of experiments was run to understand the $\mathrm{TiO}_{2}$ pathway attached to microalgae vs free $\mathrm{TiO}_{2}$. In this experiment mussels were exposed in a solution at $3.5 \mathrm{mg} / \mathrm{L} \mathrm{TiO}{ }_{2}$ with and without microalgae. Results showed in Fig. 5 indicated that mussels accumulated less $\mathrm{TiO}_{2}$ when it was unattached to microalgae. However when the statistical difference was evaluated by ANOVA, results showed that this difference was not significant at a level $\alpha \leq 0.05$ where the $\mathrm{Pr}$ $>$ F value was of 0.592 and 0.993 for the treatment (with algae and without algae) and the exposure time respectively. Thus, the Ti suspended in water or attached to microalgae seems to be equally catchable by zebra mussels. However, it can be seen that the standard deviation at an exposure time of $48 \mathrm{~h}$ was higher than the other times. Thus other factors could influence the Ti concentration identified in the tissue of mussels. Because it is know that the particle type in the environment, the particle size and the state of the $\mathrm{TiO}_{2}$ particles can affect the behavior and transport of $\mathrm{TiO}_{2}$ in the ecosystems, these parameters should be taken into account when zebra mussels are used.

The $\mathrm{Ti}$ in sediments was quantified, but in the treatment without algae, no sedimentation was observed and this did not allow the corresponding determination in an appropriate way. Thus, only the Ti concentration present in the sediments from the treatment with $\mathrm{TiO}_{2}$ algae was evaluated and results are showed in Fig. 6. It can be seen that the Ti concentration in sediments was around of 100 times higher with respect to the $\mathrm{TiO}_{2}$ concentration present in the mussel's tissue, this indicates that an important accumulation of Ti occur in sediments and the main route of Ti transport are the mussels through their filtration activity to feces deposition. A slight increase of Ti concentration in sediments as a function of exposure time after $50 \mathrm{~h}$ was observed. However, due to the standard deviation were high, conclusion cannot obtained respect to the increase of $\mathrm{Ti}$ as a function of exposure time.

\section{Conclusion}

Zebra mussels (Dreissena polymorpha) showed almost complete Ti detoxification capacity when they were exposed to $\mathrm{TiO}_{2}$ concentration lower to $3.5 \mathrm{ppm}$. However, when mussels were exposed to a $\mathrm{TiO}_{2}$ concentration of $3.5 \mathrm{ppm}$, the detoxification capacity of mussels was limited and then Ti was also accumulated in their tissues. On the other hand, it was observed that zebra mussels adsorbed Ti freely dissolved or suspended in organic matter present in the environment and that the main way of Ti magnification from zebra mussels was through the Ti accumulated in sediments.

\section{Acknowledgements}

Our sincere thanks go to the Institut National de la Recherche scientifique-Centre Eau Terre Environnement (INRS-ETE), NSERC, Technological Superior Institute of Perote (ITSPe) and the Program for the Professional development of Professors (Prodep-Mexico). Special 
thanks to Prof. Patrice Couture for helping with the environmental chamber, Professor Landis Hare for collaboration with the aquaria equipment, Prof. Isabelle Laurion for collaboration with the obtainment of the microalgae and Sarma Saurabh for the collaboration with complementary materials. We would also like to acknowledge to the administrative staff of the Port of Quebec marina for facilitating the access for the collection of the invasive mussels.

\section{Declaration of interest}

The authors declare that they have no conflict of interest.

\section{References}

Bourgeault, A., Cousin, C., Geertsen, V., Cassier-Chauvat, C., Chauvat, F., Durupthy, O. Chaneac, C., Spalla, O., 2015. The challenge of studying TiO2 nanoparticle bioaccumulation at environmental concentrations: crucial use of a stable isotope tracer. Environ. Sci. Technol. 49, 2451-2459.

Bruner, K.A., Fisher, S.W., Landrum, P.F., 1994. The role of the zebra mussel, Dreissena Polymorpha, in contaminant cycling: II. Zebra mussel contaminant accumulation from algae and suspended particles, and transfer to the benthic invertebrate, Gammarus Fasciatus. J. Great Lakes Res. 20, 735-750.

Couleau, N., Techer, D., Pagnout, C., Jomini, S., Foucaud, L., Laval-Gilly, P., Falla, J., Bennasroune, A., 2012. Hemocyte responses of Dreissena Polymorpha following a short-term in vivo exposure to titanium dioxide nanoparticles: preliminary investigations. Sci. Total Environ. 438, 490-497.

GISD, G. I. S. D, 2014. Available from. http://www.issg.org/database, Accessed date: 15 May 2014.

Kwon, T.D., Fisher, S.W., Kim, G.W., Hwang, H., Kim, J.E., 2006. Trophic transfer and biotransformation of polychlorinated biphenyls in zebra mussel, round goby, and smallmouth bass in Lake Erie, USA. Environ. Toxicol. Chem. 25, 1068-1078.
Montgomery, D.C., 2001. Design and Analysis of Experiments. John Wiley \& Sons.

Morales, J., Flechoso, F., Lizana, M., Negro, A., 2013. Patrones de colonización y ecología de poblaciones de dos bivalvos invasores (mejillón cebra Dreissena polymorpha Pallas, 1771 y almeja asiática Corbicula fluminea Müller, 1774) en un tramo lótico del Ebro medio (Castejón, Navarra). Munibe (Ciencias Naturales-Natur Zientziak), pp. 47-69.

Palais, F., Dedourge-Geffard, O., Beaudon, A., Pain-Devin, S., Trapp, J., Geffard, O., NOURY, P., Gourlay-Francé, C., Uher, E., Mouneyrac, C., 2012. One-year monitoring of core biomarker and digestive enzyme responses in transplanted zebra mussels (Dreissena Polymorpha). Ecotoxicology 21, 888-905.

Perez-Fuentetaja, A., Mackintosh, S.A., Zimmerman, L.R., Clapsadl, M.D., Alaee, M., Aga, D.S., 2015. Trophic transfer of flame retardants (PBDEs) in the food web of Lake Erie. Can. J. Fish. Aquat. Sci. 72, 1886-1896.

Ricciardi, A., Whoriskey, F., Rasmussen, J., 1996. Impact of the (Dreissena) invasion on native unionid bivalves in the upper St. Lawrence River. Can. J. Fish. Aquat. Sci. 53, $1434-1444$

Sendra, M., Yeste, M.P., Gatica, J.M., Moreno-Garrido, I., Blasco, J., 2017. Homoagglomeration and heteroagglomeration of TiO2, in nanoparticle and bulk form, onto freshwater and marine microalgae. Sci. Total Environ. 592, 403-411.

Smolders, R., Bervoets, L., De Coen, W., Blust, R., 2004. Cellular energy allocation in zebra mussels exposed along a pollution gradient: linking cellular effects to higher levels of biological organization. Environ. Pollut. 129, 99-112.

USGC-NAS, 2014. online available at. https://nas.er.usgs.gov/.

Voets, J., Redeker, E.S., Blust, R., Bervoets, L., 2009. Differences in metal sequestration between zebra mussels from clean and polluted field locations. Aquat. Toxicol. 93, 53-60.

Wigginton, N.S., Haus, K.L., Hochella Jr, M.F., 2007. Aquatic environmental nanoparticles. J. Environ. Monit. 9 (12), 1306-1316.

Yoo, A., Lord, P., Wong, W.H., 2014. Zebra mussel (Dreissena Polymorpha) monitoring using navigation buoys. Manag. Biol. Invasions 5, 159-163. 